\title{
GAMBARAN KLINIS DAN RADIOLOGIS MENURUT KELLGREN AND LAWRENCE PADA PENDERITA OSTEOARTHRITIS GENU YANG BEROBAT JALAN DI POLIKLINIK ORTOPEDI RSU ANUTAPURA PALU TAHUN 2018
}

\author{
Wulan Permatasari ${ }^{1}$, Mukramin Amran ${ }^{2}$ \\ ${ }^{1}$ Program Studi Pendidikan Dokter, Fakultas Kedokteran Universitas Alkhairat Palu \\ ${ }^{2}$ Bagian Radiologi, Fakultas Kedokteran Universitas Alkhairat Palu \\ Email: a.mukramin@yahoo.com
}

\begin{abstract}
Osteoarthritis (OA) is a progressive and degenerative chronic musculoskeletal disease caused by thinning of the cartilage in the joint due to bone rubbing against each other. History of the patient's, clinical picture of the physical examination and the results of the radiological examination are basic things to diagnose OA. Patient's complaints include joint pain which is a major complaint that brings the patient to the doctor, joint stiffness, crepitation, joint swelling, and changes in gait. Gait changes due to pain are found on a physical examination even though radiologically is still at an initial level. In addition it can be found that crepitus, swollen joints are often asymmetrical. The aim of this study was to determine clinical and radiological features by counselor and Lawrence of outpatient genotypes osteoarthritis patients in the Orthopedic Clinic RSU Anutapura Palu in 2018. Descriptive research methods were conducted on 27 people with genital osteoarthritis who were treated at the Orthopedic Clinic RSU Anutapura in 2018. Consecutive sampling was used and data collection through interviews and observations in the form of pain, joint stiffness, crepitus, joint swelling and gait changes and radiological examinations based on Kellgren and Lawrence criteria. Data analysis using SPSS 25 with frequency distribution test. The results of the study were (1) based on the clinical picture in genu osteoarthritis patients pain (100\%), pain accompanied by gait changes $(70.37 \%)$, pain accompanied by joint stiffness $(51.4 \%)$, pain accompanied by joint swelling $(44,4 \%)$, and pain with crepitus $(37.0 \%)$. (2) based on radiology in patients with osteoarthritis genu with the highest grade 3 and 4 respectively (33.3\%), grade $2(29.6 \%)$, grade $1(3.7 \%)$ and in grade 0 not found. Conclusion: found joint pain and a small portion of pain accompanied by crepitus, radiologists found in most grades 3 and 4 while grade 0 was not found.
\end{abstract}

Keywords: Osteoarthritis (OA), people with osteoarthritis, kellgren and lawrence

\section{Abstrak}

Osteoarthritis (OA) adalah penyakit muskuloskeletal kronis progresif dan degeneratif yang disebabkan penipisan tulang rawan pada sendi akibat tulang yang saling bergesekan. Anamnesis riwayat penyakit penderita, gambaran klinis dari pemeriksaan fisik dan hasil pemeriksaan radiologis merupakan hal dasar untuk mendiagnosis OA. Keluhan pasien meliputi nyeri sendi yang merupakan keluhan utama yang membawa pasien ke dokter, kekakuan sendi, krepitasi, pembengkakan sendi, dan perubahan gaya berjalan. Perubahan gaya berjalan akibat nyeri ditemukan pada pemeriksaan fisik meskipun secara radiologis masih berada pada derajat awal. Selain itu dapat ditemukan adanya krepitasi, pembengkakan sendi yang seringkali asimetris. Penelitian ini bertujuan untuk mengetahui gambaran klinis dan radiologis menurut Kellgren and Lawrence penderita osteoarthritis genu yang berobat jalan di poliklinik ortopedi rsu anutapura palu tahun 2018. Metode penelitian deskriptif pada 27 orang penderita osteoarthritis genu yang berobat di Poliklinik Ortopedi RSU Anutapura Palu 2018. Digunakan consecutive sampling dan pengumpulan data melalui wawancara dan observasi berupa nyeri, kekakuan sendi, krepitasi, pembengkakan sendi dan perubahan gaya berjalan dan pemeriksaan radiologis berdasarkan kriteria kellgren and lawrence. Analisis data menggunakan SPSS 25 dengan uji distribusi frekuensi. Hasil penelitian yakni (1) berdasarkan gambaran klinis pada penderita osteoarthritis genu didapatkan nyeri $(100 \%)$, nyeri disertai perubahan gaya berjalan $(70,37 \%)$, nyeri disertai kekakuan sendi $(51,4 \%)$, nyeri disertai pembengkakan sendi $(44,4 \%)$, dan nyeri disertai krepitasi $(37,0 \%)$. (2) berdasarkan radiologis pada penderita osteoarthritis genu terbanyak grade 3 dan 4 masing-masing $(33,3 \%)$, grade $2(29,6 \%)$, grade $1(3,7 \%)$ dan 
pada grade 0 tidak ditemukan. Kesimpulan: ditemukan nyeri sendi dan sebagian kecil nyeri yang disertai krepitasi, radiologis yang ditemukan sebagian besar grade 3 dan 4 sedangkan grade 0 tidak ditemukan.

Kata Kunci : Osteoarthritis (OA), penderita osteoarthritis, kellgren and lawrence

\section{PENDAHULUAN}

Osteoarthritis (OA) adalah penyakit muskuloskeletal kronis progresif ${ }^{1}$ dan degeneratif yang disebabkan penipisan tulang rawan pada sendi akibat tulang yang saling bergesekan, menimbulkan gejala klinis nyeri, kekakuan sendi, pembengkakan sendi, krepitasi, serta perubahan gaya berjalan. 2,3,4 $^{2,3}$

Osteoarhtritis genu adalah gangguan sinovial di sendi genu yang di tandai dengan disintegrasi tulang rawan pada sendi genu yang disertai dengan gangguan pertumbuhan tulang rawan, osteofit pada tulang, sinovitis ringan, fibrosis kapsuler, pembentukan kista dan sclerosis pada lapisan sub-kondral tulang. OA di bagi dalam beberapa derajat keparahan berdasarkan dari` gambaran radiografis yang di kenal sebagai kriteria Kellgren dan Lawrence dan di bagi mulai dari derajat $0,1,2,3$ dan $4 .{ }^{5}$

Osteoarthritis Genu merupakan masalah kesehatan yang sering di temukan. Masalah penderita osteoarthritis tidak hanya penurunan kualitas dan fungsi hidup individu, tetapi juga masalah fraktur yang sangat mudah terjadi jika penderita osteoarthritis lambat atau tidak di bawa ke RS penderita bisa mendapat komplikasi kelumpuhan atau kecacatan. Anamnesis riwayat penyakit penderita, gambaran klinis dari pemeriksaan fisik dan hasil pemeriksaan radiologis merupakan hal dasar untuk mendiagnosis OA. Keluhan pasien meliputi nyeri sendi yang merupakan keluhan utama yang membawa pasien ke dokter, kekakuan sendi, krepitasi, pembengkakan sendi, dan perubahan gaya berjalan. Perubahan gaya berjalan akibat nyeri ditemukan pada pemeriksaan fisik. Selain itu dapat ditemukan adanya krepitasi, pembengkakan sendi yang seringkali asimetris oleh karena itu tujuan dari penelitian ini adalah untuk mengetahui gambaran klinis dan radiologis penderita osteoarthritis lutut menurut kellgren and Lawrence. ${ }^{8,9}$

Menurut data RSU Anutapura Palu tercatat penderita nyeri pada sendi pada tahun 2014 tercatat sekitar 159 kasus, tahun 2015 tercatat sekitar 267 kasus, tahun 2016 tercatat 311 kasus, tahun 2017 tercatat 327 kasus. Prevalensi penyakit ini meningkat secara signifikan di antara orang-orang yang berusia lebih dari 50 tahun, akibat perubahan pada kolagen dan proteoglikan akibat usia yang mengurangi kekuatan dari sendi, tulang rawan serta berkurangnya pasokan nutrisi berkurang ke tulang rawan. ${ }^{6}$

Wanita memiliki osteoartritis genu lebih sering daripada pria, dengan rasio kejadian antara wanita dengan pria adalah 1,7: 1. Wanita juga lebih rentan terhadap osteoarthritis erosif, dengan rasio perbandingan antara perempuan dengan laki-laki \pm 12 : $1 .{ }^{6}$ Osteoatrithis dapat mengenai sendi panggul (19,6\%), lutut (25,4\%), kaki (0,1-61\%), dan lebih dari satu sendi $( \pm 22 \%){ }^{7}$ Maka berdasarkan uraian diatas, dilakukan penelitian tentang bagaimana gambaran klinis dan radiologis menurut Kellgren and Lawrence penderita Osteoarthritis Genu yang berobat di Poliklinik Ortopedi RSU Anutapura Palu tahun 2018.

\section{METODE PENILITIAN}

Metode penelitian yang digunakan adalah metode deskriptif observasional dengan pendekatan Cross Sectional. Penelitian dilakukan pada bulan Maret sampai Mei Tahun 2018 diPoliklinik ortopedi RSU Anutapura Palu. Populasi dalam penelitian ini adalah 
seluruh pasien yang telah di diagnosis dokter menderita penyakit Osteoarthritis genu yang berobat jalan di Poliklinik Ortopedi RSU Anutapura Palu tahun 2018. Subjek Penelitian adalah seluruh penderita Osteoarthritis genu yang dirawat jalan di Poliklinik Ortopedi Anutapura pada tahun 2018 dan sesuai dengan kriteria penelitian. Kriteria inklusi dalam penelitian ini yakni pasien perempuan dan laki-laki, Pasien yang didiagnosa osteoarthritis genu oleh dokter di Poliklinik Ortopedi RSU Anutapura Palu yang memiliki foto x-ray (rontgent), pasien yang bersedia ikut dalam penelitian tanpa paksaan dan telah mendapat penjelasan. Kriteria Ekslusi penelitian adalah pasien yang mengalami gangguan jiwa, pasien yang tidak dapat berkomunikasi dengan baik.

Teknik pengambilan sampel menggunakan Non-Probability Sampling, Yaitu Consecutive Sampling dengan mengambil semua penderita di diagnosa dokter RSU Anutapura menderita osteoarthritis genu yang memenuhi kriteria penelitian diikutkan dalam penelitian sampai jumlah subyek terpenuhi.

Analisa data menggunakan program komputer SPSS 20. Uji Deskriptif untuk melihat gambaran klinis osteoarthritis genu yaitu; Nyeri, kekakuan sendi, krepitasi, pembengkakan sendi, perubahan gaya berjalan dan melihat gambaran radiologi osteoarthritis genu yaitu; grade 0 , grade 1 , grade 2 , grade 3 , grade 4 .

\section{HASIL DAN PEMBAHASAN}

Tabel 1. Distribusi gambaran klinis pasien osteoarthritis lutut

\begin{tabular}{|l|c|c|}
\hline \multicolumn{1}{|c|}{ Gambaran klinis } & Frekuensi & Presentase \\
\hline Nyeri & 27 & $100 \%$ \\
\hline $\begin{array}{l}\text { Nyeri+kekakuan } \\
\text { sendi }\end{array}$ & 10 & $37,03 \%$ \\
\hline
\end{tabular}

\begin{tabular}{|l|c|c|}
\hline Nyeri+krepitasi & 8 & $29,62 \%$ \\
\hline $\begin{array}{l}\text { Nyeri+pembengkakan } \\
\text { sendi }\end{array}$ & 13 & $48,14 \%$ \\
\hline $\begin{array}{l}\text { Nyeri+perubahan } \\
\text { gaya berjalan }\end{array}$ & 18 & $66,66 \%$ \\
\hline
\end{tabular}

Berdasarkan tabel 1 didapatkan bahwa proporsi terbanyak terdapat pada pasien osteoarthritis genu dengan gambaran klinis nyeri yaitu sebanyak 27 responden (100\%); dan gambaran klinis nyeri yang disertai dengan perubahan gaya berjalan ditemukan sebanyak 18 responden $(66,66 \%)$ dari keseluruhan pasien osteoarthritis genu, sedangkan paling sedikit menderita gambaran klinis nyeri disertai dengan krepitasi yaitu 8 responden $(29,62 \%)$ dari seluruh pasien osteoartrhritis genu.

Tabel 2. Distribusi radiologis penderita osteoarthritis genu

\begin{tabular}{|l|c|c|}
\hline $\begin{array}{l}\text { Variabel } \\
\text { Gambaran } \\
\text { radiologis }\end{array}$ & $\mathbf{N}$ & $\mathbf{\%}$ \\
\hline Grade 0 & 0 & $0 \%$ \\
\hline Grade 1 & 1 & $3,7 \%$ \\
\hline Grade 2 & 8 & $29,6 \%$ \\
\hline Grade 3 & 9 & $33,3 \%$ \\
\hline Grade 4 & 9 & $33,3 \%$ \\
\hline Total & 27 & $100 \%$ \\
\hline
\end{tabular}

Berdasarkan tabel 2 didapatkan bahwa proporsi terbanyak terdapat pada pasien osteoarthritis genu dengan skor Kellgren and lawrence adalah grade 3 dan grade 4 masing-masing sebanyak 9 responden $(33,3 \%)$ kemudian untuk gambaran radiologis grade 2 sebanyak 8 responden $(29,6 \%)$ dan paling sedikit adalah grade 1 yaitu 1 responden $(3,7 \%)$ sedangkan pada grade 0 tidak ditemukan. 


\section{Gambaran Klinis Penderita Osteoarthritis}

Dari hasil penelitian menurut gambaran klinis penderita osteoarthritis keluhan utama terbanyak yang dikeluhkan pasien datang kerumah sakit adalah nyeri lutut, dengan total sebanyak 27 responden (100\%). Hal ini sesuai dengan penelitian yang dilakukan oleh Bunga (2015), yang menyatakan bahwa keluhan yang paling sering dirasakan oleh pasien adalah nyeri sendi. Kepustakaan menyatakan bahwa nyeri merupakan keluhan utama pada pasien osteoartritis. Nyeri biasanya bertambah dengan gerakan dan sedikit berkurang dengan istirahat. Nyeri yang timbul berasal dari peradangan sendi (sinovitis), efusi sendi dan edema sumsum tulang. Gambaran klinis yang lain yaitu nyeri yang disertai perubahan gaya berjalan yaitu sebanyak 18 responden $(66,66 \%)$ hal tersebut hampir sejalan dengan penelitian yang dilakukan oleh Regi M 2014 yang menyatakan perubahan gaya berjalan merupakan keadaan yang berhubungan dengan nyeri karena menjadi tumpuan berat badan terutama pada osteosarthritis genu. Gambaran lain yang dikeluhkan pasien osteoarthritis genu adalah nyeri yang disertai dengan pembengkakan sendi yaitu sebanyak 13 responden $(48,14 \%)$ hal ini sesuai dengan penelitian Regi M (2014), nyeri dan edema dapat timbul akibat periosteum tidak terlindungi lagi. Kondrosit yang tidak dapat melindungi matriks dapat menyebabkan terjadinya inflamasi pada sinovial. Hal ini ditandai dengan adanya rasa sakit pada genu (lutut). Kekakuan sendi juga ditemukan pada penelitian ini, keluhan kaku sendi yang disertai dengan keluhan nyeri, dirasakan oleh 10 responden $(37,03 \%)$ kekakuan tersebut diakibatkan oleh sendi yang tidak digerakan dalam waktu lama hal ini sesuai dengan penelitian yang dilakukan oleh Bunga (2015). Krepitasi pada penelitian ini merupakan keluhan yang paling sedikit yaitu 8 responden $(29,62 \%)$ krepitasi merupakan rasa gemertak yang disebabkan oleh hilangnya tulang rawan.

\section{Gambaran Radiologi Osteoarthritis}

Dari hasil penelitian menurut gambaran radiologis penderita osteoarthritis genu dengan skor Kellgren and Larence terbanyak adalah grade 3 dan 4 yaitu masingmasing sebanyak 9 responden $(33,3 \%)$. Hal tersebut hampir sejalan dengan penelitian yang dilakukan oleh Bedson John (2008). Kellgren and Lawrence telah menetapkan penyempitan celah sendi yang jelas sebagai grade 3 begitu juga dengan grade 4 namun dibedakan pada osteofit, dimana grade 3 osteofit multiple sedangkan grade 4 osteofit yang besar. Gambaran radiologis yang lain ditemukan adalah grade 2 yaitu sebanyak 8 responden $(29,6 \%)$. Hal ini hampir sejalan dengan penelitian yang dilakukan john Bedson. Sedangkan grade 1 sebanyak 1 responden $(3,7 \%)$ menurut Kellgren and Lawrence grade 1 mempunyai osteofit yang belum jelas dan grade 2 mempunyai osteofit yang jelas disertai dengan penyempitan celah sendi. Penelitian sebelumnya mengenai prevalensi osteoarthritis genu secara radiologis di Amerika Serikat, dilakukan oleh reva. Lawrence dkk (2008), dengan meneliti peserta yang berpartisipasi dalam studi Framingham, Projek Johnton County Osteoarthritis dan NHANES III (The National Health and Nutrition Examination Survey).

\section{DAFTAR PUSTAKA}

1. Anggraini Enestasia Niken, Hendrat Yovita Lucia. 2014. Hubungan Obesitas dan Faktor-Faktor Pada Individu dengan Kejadian Osteoarthritis Genu.

2. Cooper $\mathrm{C}$ et al. 2013. How to define responders in osteoarthritis. Washington DC: Medscape.

3. Wittenauer R et al. 2013. Priority medicines for europe and the world a public health approach to innovation.

4. Atos healthcare. 2015. Department of social protection osteoarthritis.

5. Alhambra daniel P et al. 2014. Osteoarthritis second edition. 
6. Lozada Carlod J et al. 2015. Proggresion of osteoarhritis.

7. Allen K D et al. 2015. Epidemiology of osteoarthritis.

8. Lourenco Sara et al. 2014. Osteoarthritis medical labelling and health related quality of life in the general population.

9. Centers for disease control and prevention. 2017. Osteoarthritis. Atlanta: Centers for disease control and prevention.

10. Bedson John; Croft R Peter. 2008. The discordance between clinical and radiographic knee osteoarthritis genu.

11. Sonjaya Muhammad Regi et al. 2014. Karakteristik pasien osteoarthritis di poliklinik ortopedi rumah sakit al-islam bandung. 